\title{
Expression and anticancer activity analysis of recombinant human $\mathrm{uPA}_{1-43}$-melittin
}

\author{
MANMAN SU ${ }^{1,2}$, WEIQIN CHANG ${ }^{1}$, MANHUA CUI $^{1}$, YANG LIN $^{1}$, SHUYING WU ${ }^{1}$ and TIANMIN XU ${ }^{1}$ \\ ${ }^{1}$ The Second Hospital, ${ }^{2}$ Department of Regenerative Medicine, College of Pharmacy, Jilin University, Changchun, P.R. China
}

Received July 12, 2014; Accepted October 24, 2014

DOI: $10.3892 /$ ijo.2014.2750

\begin{abstract}
The present study is focused on expression of a target fusion protein which can be used in ovarian cancer target therapy. It aimed to construct human urokinase-type plasminogen activator (uPA) $)_{1-43}$-melittin eukaryotic expression vector to express recombinant human $\mathrm{uPA}_{1-43}$-melittin (rhuPA $_{1-43}$-melittin) in $P$. pastoris and to detect its anticancer effects on ovarian cancer cells. The DNA sequences that encode $\mathrm{uPA}_{1-43}$ amino acids and melittin were synthesized according to its native amino acid sequences and consequently inserted into pPICZ $\alpha \mathrm{C}$ vector. Then $\mathrm{uPA}_{1-43}$-melittin -pPICZ $\alpha \mathrm{C}$ was transformed into $P$. pastoris $\mathrm{X}-33$, and rhuPA ${ }_{1-43}$-melittin was expressed by methonal inducing. The bioactivities of recombinant fusion protein were detected with inhibition effects on growth of ovarian cancer cells, cell cycle detection and TUNEL assay. The results of DNA sequence analysis of the recombinant vector $\mathrm{uPA}_{1-43}$-melittin -pPICZ $\alpha \mathrm{C}$ demonstrated that the DNA encoding human uPA 1-43 amino acids and 1-26 amino acids of melittin was correctly inserted into the pPICZ $\alpha \mathrm{C}$ vector. After being induced by methonal, fusion protein with molecular weight $7.6 \mathrm{kDa}$ was observed on the basis of SDS-PAGE and western blot analysis. The recombinant protein was able to suppress growth of SKOV3, induce cell cycle arrest and apoptosis of SKOV3 cells. The fusion protein does not have any obvious toxicity on normal tissues.
\end{abstract}

Correspondence to: Dr Tianmin Xu, Department of Obstetrics and Gynecology, The Second Hospital, Jilin University, 218 Zi Qiang Street, Changchun 130041, P.R. China

E-mail: tianminxu@aliyun.com

Abbreviations: uPA, urokinase plasminogen activator; uPAR, urokinase plasminogen activator receptor; ATF, amino-terminal fragment; EGF-domain, epidermal growth factor-like domain; GPI, glycosylphosphatidylinositol; rhuPA $1-43$-melittin, recombinant human $\mathrm{uPA}_{1-43}$-melittin; pBs, plasmid Bluescript II; YPD, yeast extract peptone dextrose; TFA, trifluoroacetic acid; DAB, 3,3'-diaminobenzidine; ELISA, enzyme-linked immunosorbent assay; FBS, fetal bovine serum; PBS, phosphate-buffered saline; OPD, ortho-phenylenediamine

Key words: urokinase plasminogen activator, melittin, Pichia pastoris, ovarian cancer, fusion protein
$\mathrm{RhuPA}_{1-43}$-melittin was successfully expressed in P.pastoris. Taking $\mathrm{uPA}_{1-43}$ amino acids specifically binding to uPAR as targeted part of fusion protein, and making use of antitumor activity of melittin, the recombinant fusion protein it was able to inhibit growth of ovarian tumors and to be applied for effective targeted treatment.

\section{Introduction}

Metastasis is a multi-step process that involves spreading of cancer cells from the primary to the secondary site. During this process, cancer cells must invade the surrounding tissue, penetrate the blood or lymphatic vessels, and form a new tumor mass at distant sites (1). This process requires the participation of several proteolytic enzyme systems, such as serine proteases and metalloproteases (2). Urokinase plasminogen activator (uPA) is a serine protease that interacts with its receptor, the uPA receptor (UPAR). After activation, cell-bound uPA is capable of converting plasminogen into plasmin, which is then able to regulate multiple pathways that are involved in matrix degradation, cell motility, metastasis and angiogenesis $(3,4)$.

uPA is synthesized as a single-chain proenzyme which is activated by proteolytic cleavage (5), to form the high-molecular-weight two-chain active uPA or the low-molecular-weight uPA through the action of plasmin, kallikrein, or cathepsin B (6). uPA is composed of a carboxyl-terminal serine protease domain and an amino-terminal fragment (ATF) that consists of an epidermal growth factor-like domain (EGF-domain) and a kringle domain (7). uPA is recruited to cell surfaces via high affinity interaction of the EGF-domain (amino acids 4-43) with the glycosylphosphatidylinositol (GPI)-anchored uPAR $(8,9)$.

The level of UPAR is undetectable or very low in the majority of normal tissues or organs (10). However, UPAR is highly expressed in many tumor types, such as ovarian, breast, pancreatic and lung cancers $(11,12)$. A high level of uPAR expression in tumor cells correlates with aggressive tumor types, tumor metastasis and poorer prognosis (13). Since studies showed that prevention of uPA from binding to UPAR decreases invasion, uPA represents a potential therapeutic target in cancer (14). A number of small molecule uPA inhibitors have been developed, however, most of these inhibitors lack sufficiently documented specificity (7).

Melittin, a major component of bee venom, is a 26 -amino acid polypeptide. It has been reported to have multiple effects, 
such as anti-inflammatory, anti-arthritic, and anti-virus effects in various cell types (15). It has also been reported to have induced apoptosis, cell cycle arrest and growth inhibition and suppressed the signaling pathway in various tumor cells (16-18). However, the toxicity of melittin on normal tissues limits its application.

So in this study, we took advantage of uPA EGF-domain specific binding to UPAR and the antitumor effects of melittin to design and express fusion protein that contained uPA amino acids 1-43 and melittin in Pichia pastoris. The fusion protein can compete with UPA to bind UPAR and reduce toxicity of melittin on normal tissues. As a result, the recombinant fusion protein, recombinant human $\mathrm{uPA}_{1-43}$-melittin (rhuPA $_{1-43^{-}}$ melittin), was able to inhibit growth of ovarian tumors and to be applied for effective targeted treatment.

\section{Materials and methods}

Strains, vectors, and reagents. All restriction enzymes, DNA marker, and protein marker were purchased from Takara Biotechnology (Japan). The P. pastoris X-33, pPICZ $\alpha \mathrm{C}$ vector, and zeocin antibiotic were obtained from Invitrogen (CA, USA) and all primers were synthesized by Sangon Biotechnology Corp. (Shanghai, China). pPICZ $\alpha \mathrm{C}$ vector without cleavage of Ste13 was reconstructed by our lab. The murine anti-human urokinase monoclonal antibody was obtained from American Diagnostica Inc. (USA). PCR purification kit, gel extraction kit, and Miniprep kit for plasmid extraction were obtained from Sangon Biotechnology Corp. SP Sepharose XL and Source ${ }^{\mathrm{TM}} 30$ RPC reversed phase hydrophobic chromatography were purchased from Phamarcia (Sweden). YPD, BMGY, BMMY media were prepared as formula (Invitrogen). HBL100 human breast epithelial cell line and SKOV3 human ovarian cancer cell line were obtained from the type culture collection of the Chinese Academy of Sciences (Shanghai, China).

P.pastoris was grown in YPD (2\% peptone, $1 \%$ yeast extract, and $2 \%$ dextrose) or BMGY (0.1 M potassium phosphate, $2 \%$ peptone, $1 \%$ yeast extract, $1.34 \% \mathrm{YNB}$, and $1 \%$ glycerol). BMMY was used for protein induction $(0.1 \mathrm{M}$ potassium phosphate, $2 \%$ peptone, $1 \%$ yeast extract, $1.34 \%$ YNB and $0.5 \%$ methanol). YPD-zeocin plates (1\% yeast extract, $2 \%$ peptone, $2 \%$ dextrose, $2 \%$ agar, and 0.1 zeocin) were used for selecting positive transformants.

Construction of expression vector $p P I C Z \alpha C-u P A_{1-43}-$ melittin. The DNA sequence that encodes uPA amino-terminal fragment 1-43 amino acids and 26 amino acids of melittin was synthesized according to its native amino acid sequences and inserted into plasmid Bluescript II (pBs) by Sangon Biotechnology Corp. For the sake of insertion into pPICZ $\alpha \mathrm{C}$ vector and secreted expression the fusion protein, XhoI site and the $K e \times 2$ site were added to the $5^{\prime}$ end, termination codon and the EcoRI site were added to the 3' end. In order to improve the yield of the fusion protein, synonymous codons were replaced by yeast biased codons. The full length gene which we designed to express rhuPA $\mathrm{P}_{1-43}$-melittin fusion protein was as followed: ctc gag aag aga tct aac gag ttg cac caa gtt cca tct aac tgt gac tgt ttg aac ggt ggt act tgt gtt tct aac aag tac ttc tct aac att cac tgg tgt aac tgt cca aag aag ttc ggt ggt caa cac tgt gag gtt att ggt get gtt ttg aag gtt ttg act act ggt ttg cca get ttg att tct tgg att aag aga aag aga caa caa tga gaa ttc.

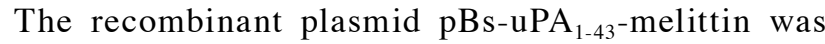
digested with $X h o \mathrm{I}$ and $E c \mathrm{ORI}$, the resulting $\mathrm{uPA}_{1-43}$-melittin DNA fragment then was inserted into the corresponding sites of the expression vector $\mathrm{pPICZ} \alpha \mathrm{C}$. Then the recombinant plasmid was transformed into competent cells of Escherichia coli XL-Blue and the recombinant colonies were selected by zeocin $(25 \mu \mathrm{g} / \mathrm{ml})$ resistance. Both the nucleotide sequences of the inserted DNA and flanking sequence were verified by sequencing with Genome Lab DTCS-Quick Start kit and CEQ 2000 DNA analysis system (Beckman, USA).

Transformation of $P$. pastoris and selection of high-level expression colonies. Plasmid DNA pPICZ $\alpha \mathrm{C}-\mathrm{uPA}_{1-43}-$ melittin was linearized with SacI and introduced into Pichia host cells $P$. pastoris X33 by electroporation using a Micropulser (Bio-Rad, USA) according to the $\mathrm{pPICZ} \alpha$ vector manual. After the electroporation, $1 \mathrm{M}$ ice-cold sorbitol was added immediately, and the cuvette contents were incubated at $30^{\circ} \mathrm{C}$ for $60 \mathrm{~min}$. The mixture was spread on yeast extract peptone dextrose (YPD) agar plates containing zeocin and cultured at $30^{\circ} \mathrm{C}$ for two days. Antibiotic zeocin was used in the concentration of $0.1 \mathrm{~g} / 1$. After the transformants with zeocin resistance appeared, some monoclonal transformants were picked up randomly from the plates and initially cultured in a 50-ml conical tube containing $10 \mathrm{ml}$ BMGY medium at $28^{\circ} \mathrm{C}$ with shaking at $225 \mathrm{rpm}$ for $24 \mathrm{~h}$. The cloned cells were then centrifuged and resuspended in $10 \mathrm{ml}$ BMMY medium to induce expression for 7 days. The culture media $(0.5 \mathrm{ml})$ were sampled per day and centrifuged at $4^{\circ} \mathrm{C}, 10,000 \mathrm{rpm}$ for $5 \mathrm{~min}$. Cell pellets and supernatant were separated. The supernatant was used for recombinant protein detection and the cell pellets were used for genomic DNA analysis. Methanol was added every $24 \mathrm{~h}$ to a final concentration of $0.5 \%(\mathrm{v} / \mathrm{v})$ for inducing the expression of the target protein. The blank plasmids of $\mathrm{pPICZ} \alpha \mathrm{C}$ were also transformed as a negative control.

Optimized expression of rhuPA $A_{1-43}$-melittin in P. pastoris. In order to achieve high level expression of rhuPA ${ }_{1-43}$-melittin, different culture parameters including $\mathrm{pH}$ value and induction time were evaluated in the expression procedure. The $\mathrm{pH}$ values were adjusted to 3.5-7.0 with 0.5 intervals. The processes were the same as above and the $\mathrm{pH}$ values were adjusted every day with disodium hydrogen phosphate and citric acid. At the desired time-points, $0.5-\mathrm{ml}$ cell aliquots were withdrawn and then replaced with equal amount of fresh medium. The supernatant samples were used for enzyme-linked immunosorbent assay.

Enzyme-linked immunosorbent assay (ELISA). Individual wells of ELISA plate (Costar,USA) were coated with $50 \mu \mathrm{l}$ supernatant sample of rhuPA ${ }_{1-43}$-melittin which had been diluted with $50 \mu \mathrm{l}$ coating buffer $\left(15 \mathrm{mM} \mathrm{Na} \mathrm{CO}_{3}, 35 \mathrm{mM}\right.$ $\left.\mathrm{NaHCO}_{3}, \mathrm{pH} 9.6\right)$ overnight at $4^{\circ} \mathrm{C}$. The plates were blocked with $5 \%(\mathrm{w} / \mathrm{v})$ non-fat milk powder in TPBS (PBS with $0.05 \%$ Tween-20) and incubated for $2 \mathrm{~h}$ at room temperature. The murine anti-human urokinase monoclonal antibody (American Diagnostica Inc., USA) was used at 1:1,000, incubated for $1 \mathrm{~h}$ at $37^{\circ} \mathrm{C}$. Following several washes with TPBS, the 
plates were incubated with goat anti-mouse $\operatorname{IgG}$ conjugated to HRP (Dingguo, China) (1:250 dilution with blocking buffer) for $1 \mathrm{~h}$ again. The color reaction was developed by addition of the substrate solution ortho-phenylenediamine (OPD) and incubated for $5 \mathrm{~min}$ at room temperature in the dark. Then $50 \mu \mathrm{l}$ stop solution $\left(2 \mathrm{M} \mathrm{H}_{2} \mathrm{SO}_{4}\right)$ was added to each well. The absorbance values at $490 \mathrm{~nm}$ were read in ELX800 Microplate Reader (Bio-Tek, USA). The reading work was finished within $2 \mathrm{~h}$ after adding the stop solution.

Large-scale expression and purification of rhuPA $A_{1-43}$-melittin. The highest-level expression transformant was cultured in a 5-1 shake flask containing $21 \mathrm{BMGY}$ medium at $28^{\circ} \mathrm{C}$ until the culture reached OD600 $=6.0$, the cells were harvested by centrifugation and resuspended in $21 \mathrm{BMMY}(\mathrm{pH} 6.0)$ medium, and cultured at $28^{\circ} \mathrm{C}$ with shaking for 4 days. Sampling of the culture medium was performed every $24 \mathrm{~h}$ to analyze cell wet weight, optical density and determine rhuPA $_{1-43}$-melittin expression based on SDS-PAGE analysis, and the culture was supplemented daily with $10 \mathrm{ml}$ methanol to a final concentration of $0.5 \%(\mathrm{v} / \mathrm{v})$ for inducing the expression of rhuPA ${ }_{1-43}$-melittin.

A cation exchange chromatographic column $(20 \mathrm{ml}, \mathrm{SP}$ Sepharose XL, Sweden) was equilibrated with $100 \mathrm{ml} 20 \mathrm{mM}$ NaAc-HAc ( $\mathrm{pH} 3.5$ ) buffer. The supernatant was collected by centrifugation at $15,000 \mathrm{rpm}$ for $10 \mathrm{~min}$ and was clarified with a $0.45-\mu \mathrm{m}$ cellulose membrane. After being diluted four times with $20 \mathrm{mM}$ NaAc-HAc (pH 3.5) buffer, the $\mathrm{pH}$ of the fermentation broth was adjusted to 3.5 with $1 \mathrm{M}$ acetate acid. The supernatant was loaded onto the cation exchange chromatographic column at the rate of $0.5 \mathrm{ml} / \mathrm{min}$. Then the column was washed extensively with the same buffer at the rate of $1 \mathrm{ml} /$ min. The bound protein was eluted with a linear gradient of $0.1-1.0 \mathrm{M} \mathrm{NaCl}$ while the flow rate was maintained at the rate of $1 \mathrm{ml} / \mathrm{min}$. Protein elution was monitored by measuring the absorbance at $280 \mathrm{~nm}$ and identified by SDS-PAGE analysis. Column effluent containing rhuPA ${ }_{1-43}$-melittin was collected and submitted to Vivaflow 200 (Sartorius Stedim, Germany) at the rate of $1 \mathrm{ml} / \mathrm{min}$ to remove impurity proteins with molecular weight $>10 \mathrm{kDa}$. Then the ultrafiltrate containing rhuPA $_{1-43}$-melittin was loaded onto a reverse phase column $(2.0 \times 15 \mathrm{~cm}$, Source 30 , Sweden) which was equilibrated with $0.1 \%$ trifluoroacetic acid (TFA) for further purification. RhuPA $_{1-43}$-melittin was eluted using $50 \%$ methanol containings $0.1 \%$ TFA and $100 \%$ methanol (containing $0.1 \%$ TFA) at the rate of $1 \mathrm{ml} / \mathrm{min}$ and monitored by measuring the UV absorbence at $280 \mathrm{~nm}$. Column effluent containing rhuPA ${ }_{1-43^{-}}$ melittin was concentrated by vacuum distillation and freeze drying to remove methanol. The finally purified rhuPA ${ }_{1-43^{-}}$ melittin was stored at $-80^{\circ} \mathrm{C}$ for further studies.

SDS-PAGE and western blot assays. SDS-PAGE analysis was performed using an $18 \%$ gel. For western blotting, proteins in the gel were transferred to a nitrocellulose membrane. The membrane was blocked with 5\% BSA for $1 \mathrm{~h}$ and then incubated with the murine anti-human urokinase monoclonal antibody for $12 \mathrm{~h}$. After being washed, the membrane was incubated with the goat anti-mouse IgG conjugated to HRP (Dingguo), diluted to 1:250. The bound antibody was detected using 3,3'-diaminobenzidine (DAB).
$N$-terminal amino acid sequence analysis. To determine the $\mathrm{N}$-terminal sequence, the purified rhuPA ${ }_{1-43}$-melittin was electrophoresed on $18 \%$ SDS-PAGE gel and electroblotted on a PVDF membrane. After being blotted, the PVDF membrane was stained with Coomassie brilliant blue R250, and the rhuPA $_{1-43}$-melittin band was cut out and determined by automated Edman degradation performed on a model PPSQ-21A protein sequencer (Shimadzu, Japan).

Inhibition effects of rhuPA $1-43$-melittin on growth of ovarian cancer cells. The growth and proliferation of SKOV3 ovarian carcinoma cells line was observed with MTT assay. Briefly, human ovarian cancer SKOV3 cells were maintained in H-DMEM with $10 \%$ fetal bovine serum (FBS) and $100 \mathrm{U} / \mathrm{ml}$ of penicillin/streptomycin, at $37^{\circ} \mathrm{C}$ in humidified atmosphere containing $5 \% \mathrm{CO}_{2}$. Cells $\left(1 \times 10^{4}\right)$ were seeded in 96-well plates containing complete medium and incubated for $24 \mathrm{~h}$ followed by different doses of rhuPA $1-43$-melittin for $24 \mathrm{~h}$. SKOV3 were treated by H-DMEM (as control) and 5, 10, 20,40 and $80 \mu \mathrm{g} / \mathrm{ml}$ rhuPA $_{1-43}$-melittin, respectively. Then $20 \mu \mathrm{l}$ MTT solution $(5 \mathrm{mg} / \mathrm{ml})$ was added to each well. After being incubated for a further $4 \mathrm{~h}$ at $37^{\circ} \mathrm{C}$, the culture medium including MTT solution in the well was removed, and $150 \mu \mathrm{l}$ DMSO was added to each well and mixed thoroughly to dissolve the crystals. Then the absorbance at $490 \mathrm{~nm}$ was detected (Bio-Rad Instruments, USA).

To test the effect of rhuPA $1-43$-melittin on normal cell proliferation, human breast epithelial cells HBL100 were plated as above and incubated for $24 \mathrm{~h}$ followed by different doses of rhuPA $1-43$-melittin for $24 \mathrm{~h}$. HBL100 were treated by RPMI-1640 (as control) and 5, 10, 20, 40 and $80 \mu \mathrm{g} / \mathrm{ml}$ rhuPA $_{1-43}$-melittin, respectively. MTT assay was performed as above.

Cell cycle detection. Cell cycle analysis was performed using propidium iodide staining. Briefly, the SKOV3 cells were seeded in a 6-well plate. After being treated by H-DMEM (as

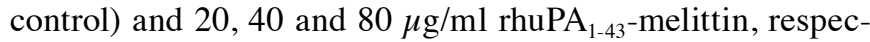
tively, the cells were washed twice with phosphate-buffered saline (PBS), and then fixed in $70 \%$ ethanol overnight. After being washed twice in PBS, the cells were stained in propidium iodide $(50 \mu \mathrm{g} / \mathrm{ml})$ in the presence of $50 \mu \mathrm{g} / \mathrm{ml} \mathrm{RNase}$ (DNase free) for $30 \mathrm{~min}$. Flow cytometry (BD Biosciences, USA) was used to detect the cell cycle and a quantitative analysis of the cell cycle distribution was carried out using a trial version of ModFit LT V3.0 software (Verity Software House, USA). The results are expressed as percentage of the cells in each phase.

TUNEL assay for apoptosis. Apoptosis was determined by TUNEL assay. SKOV3 cells at density of $1 \times 10^{5}$ cells/well were seeded onto $1.3 \mathrm{~mm}$ coverslips in 24-well plates and incubated for $24 \mathrm{~h}$ followed by different doses of rhuPA ${ }_{1-43^{-}}$ melittin for $24 \mathrm{~h}$. SKOV3 cells were treated by H-DMEM (as control), 20, 40 and $80 \mu \mathrm{g} / \mathrm{ml} \mathrm{rhuPA}_{1-43}$-melittin respectively and the cells were fixed with freshly prepared paraformaldehyde [4\% in PBS ( $\mathrm{pH} \mathrm{7.4)],} \mathrm{rinsed} \mathrm{with} \mathrm{PBS,} \mathrm{and} \mathrm{incubated}$ in permeabilization solution. TUNEL staining was performed with an in situ cell death detection kit (Bioss, China) according to the manufacturer's protocol. The TUNEL reaction mixture 


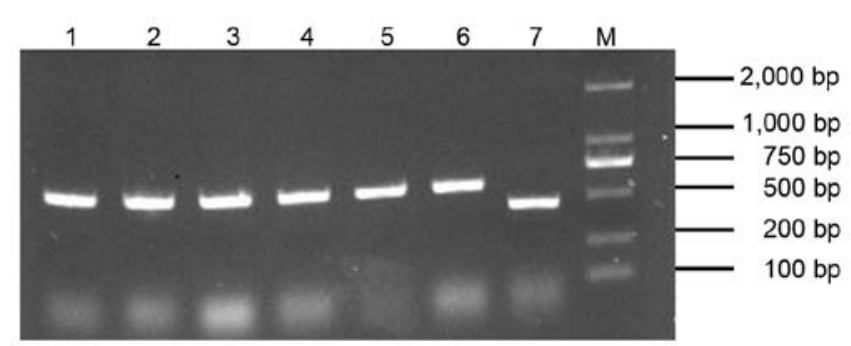

Figure 1. Agarose gel electrophoresis analysis of PCR product of the yeast genomic DNA. Lane M, DL2000 marker (Takara). Lanes 1-6, PCR products of yeast genomic DNA transformed with $\mathrm{uPA}_{1-43}$-melittin-pPICZ $\alpha$. Lane 7, PCR product of yeast genomic DNA transformed with pPICZ $\alpha \mathrm{C}$ blank plasmid.

containing reaction buffer, terminal deoxynucleotidyl transferase, and bromodeoxyuridine triphosphate was added onto the slides and incubated for $2 \mathrm{~h}$ at $37^{\circ} \mathrm{C}$, followed by washing and incubation with an HRP-labeled anti-bromodeoxyuridine monoclonal antibody for $30 \mathrm{~min}$ at room temperature. The presence of antigen was then visualized with diaminobenzidine. Slides were subsequently counterstained with hematoxylin and imaged under bright-field microscopy. The number of TUNEL-positive cells was counted in six different fields and representative fields were photographed. The percentages of apoptotic cells were calculated from the ratio of apoptotic cells to total cells counted.

\section{Results}

Construction and transformation of pPICZ $\alpha C-u P A_{1-43^{-}}$ melittin. Results of DNA sequence analysis of the recombinant expression vector pPICZ $\alpha \mathrm{C}-\mathrm{uPA}_{1-43}$-melittin (data not shown) demonstrated that the DNA sequences encoding human uPA amino acids 1-43 and melittin were correctly inserted into pPICZ $\alpha \mathrm{C}$ vector and the amino acid sequence of $\mathrm{uPA}_{1-43}$-melittin encoding was identical with that logged in GenBank.

After being cultured at $30^{\circ} \mathrm{C}$ for 2 days, dozens of transformants with zeocin resistance appeared on YPD agar plates which contained $0.1 \mathrm{~g} / 1$ zeocin. The PCR analysis of genomic DNA showed that the DNA sequence encoding human uPA amino acids 1-43 and melittin was indeed integrated into over $90 \%$ of clones which transformed with recombinant expression vector $\mathrm{pPICZ} \alpha \mathrm{C}-\mathrm{uPA}_{1-43}$-melittin. There were $\sim 600 \mathrm{bp}$ amplification bands for the samples that were transformed with pPICZ $\alpha \mathrm{C}-\mathrm{uPA}_{1-43}$-melittin, however, $400 \mathrm{bp}$ for the control sample which was transformed with pPICZ $\alpha \mathrm{C}$ blank plasmid (Fig. 1).

Expression and detection of rhuPA ${ }_{1-43}$-melittin in P. pastoris. After induction with methanol for rhuPA ${ }_{1-43}$-melittin expression, one of the transformants which presented the highest expression level of rhuPA $1-43$-melittin could be used for further experiments. SDS-PAGE analysis of rhuPA ${ }_{1-43}-$ melittin culture medium indicated that rhuPA $\mathrm{PA}_{1-43}$-melittin expressed after the induction of methanol, however, the rhuPA ${ }_{1-43}$-melittin expression in the transformant containing blank plasmids of pPICZ $\alpha \mathrm{C}$ was negative. Based on the amino acid sequence, the

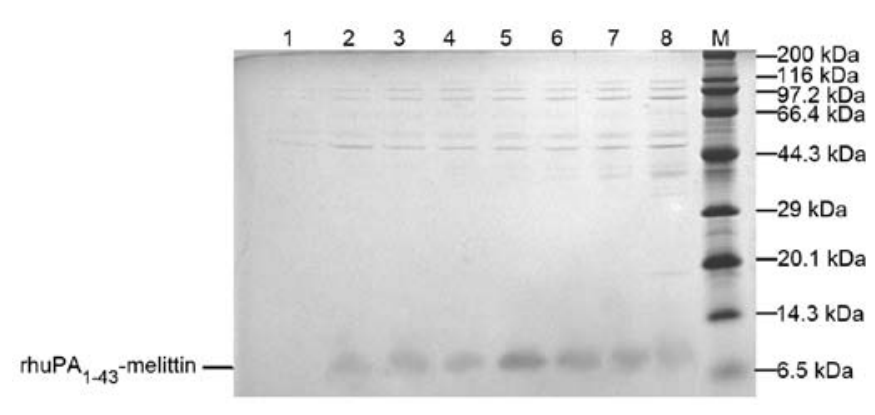

Figure 2. SDS-PAGE analysis of rhuPA ${ }_{1-43}$-melittin. SDS-PAGE was performed on an $18 \%$ gel and stained with Coomassie brilliant blue. Lane M, protein molecular weight marker (broad). Lane 1, supernatant from the negative stain trasformed with pPICZ $\alpha$ blank plasmids. Lanes 2-8, supernatant from rhuPA $\mathrm{P}_{1-43}$-melittin transformants after induction by methanol for 24,48 , $72,96,120,144$ and $168 \mathrm{~h}$, respectively.

Table I. Purification process of rhuPA1-43-melittin.

\begin{tabular}{lcccc}
\hline $\begin{array}{l}\text { Purification } \\
\text { Steps }\end{array}$ & $\begin{array}{c}\text { Total } \\
\text { protein } \\
(\mathrm{mg})\end{array}$ & $\begin{array}{c}\text { rhApoC-I } \\
(\mathrm{mg})\end{array}$ & $\begin{array}{c}\text { Recovery } \\
(\%)\end{array}$ & $\begin{array}{c}\text { Purity } \\
(\%)\end{array}$ \\
\hline Supenatant & 128 & 96 & & 75 \\
SP Sepharose XL & 93 & 78 & 81.3 & 83.0 \\
Vivaflow 200 & 76 & 69 & 71.9 & 90.8 \\
Source 30 RPC & 70 & 66 & 68.9 & 94.2 \\
\hline
\end{tabular}

calculated molecular weight of rhuPA $\mathrm{P}_{1-43}$-melittin was $7.6 \mathrm{kDa}$, which was consistent with the result of SDS-PAGE measurement (Fig. 2).

Optimized expression of rhuPA $A_{1-43}$-melittin in P. pastoris. The transformant that presented the highest expression level was chosen for scaled-up protein production. After a series of experiments, the optimal expression conditions of rhuPA ${ }_{1-43^{-}}$ melittin were obtained as follows: the optimal $\mathrm{pH}$ was 5.5 (Fig. 3a) and the optimal induction time-points was on the 4th day for the strain (Fig. 3b) at $28^{\circ} \mathrm{C}$ and with methanol daily addition concentration of $0.5 \%(\mathrm{v} / \mathrm{v})$. Under these conditions, high level expression transformant of $P$. pastoris strain was obtained and retained for further studies.

The characterization of purified rhuPA ${ }_{1-43}-$ melittin. The rhuPA $_{1-43}$-melittin supernatant was purified with a cation exchange chromatography and a reverse phase chromatography. Using an AKTA Explorer 100 chromatography system, we optimized the purification parameters. The optimal concentration of $\mathrm{NaCl}$ for elution was $0.6 \mathrm{M}$ and $100 \%$ methanol (containing $0.1 \%$ TFA) can elute the bound rhuPA ${ }_{1-43}-$ melittin from the reverse phase chromatographic column (Fig. 4a). The concise purification protocol of rhuPA $\mathrm{PA}_{1-43}$-melittin is presented in Table I.

The primary purified recombinant protein was identified by western blot analysis. The results demonstrated that the recombinant protein could bind with murine anti-human urokinase monoclonal antibody. No band was observed in lane 1, which is the supernatant before adding methanol (Fig. 4b). 

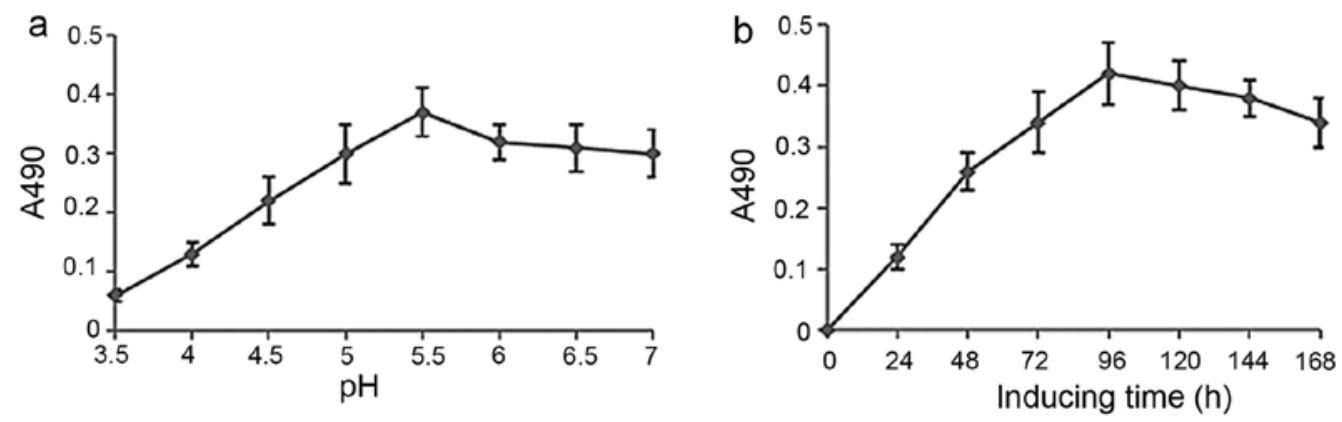

Figure 3. Optimized expression of recombinant human $\mathrm{uPA}_{1-43}$-melittin in P. pastoris. (a) Optimization of the pH value. (b) Optimization of the methanol inducing time-points. Supernatants collected at each evaluated condition were processed by ELISA analysis.
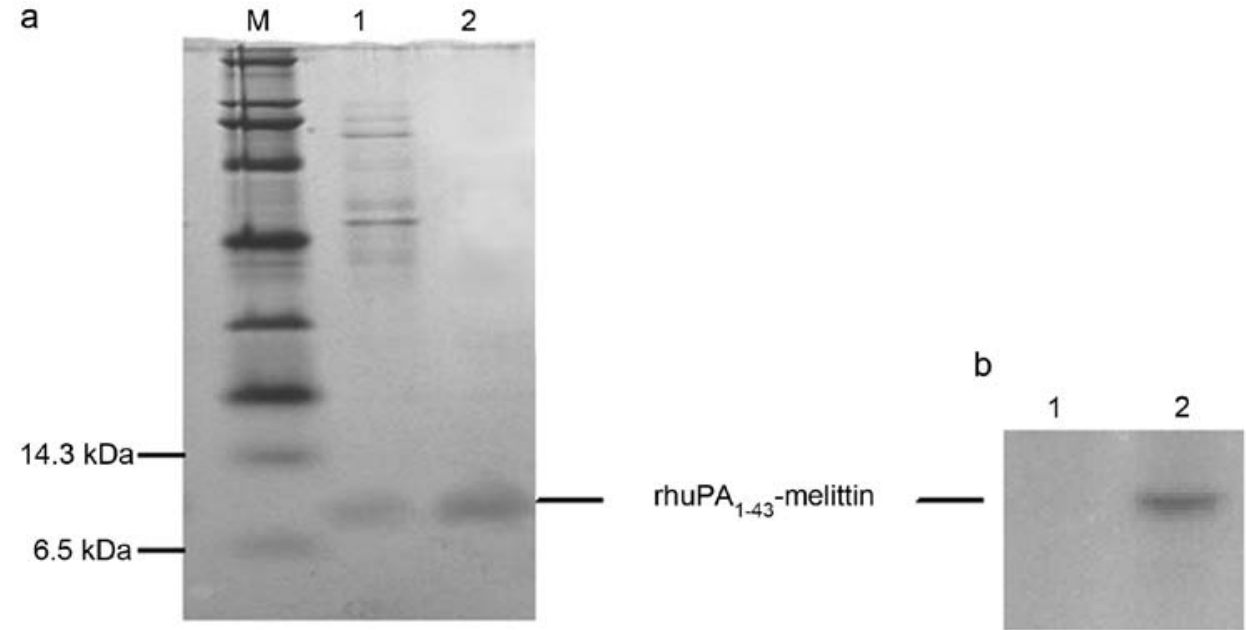

Figure 4. Purification and identification of recombinant human $\mathrm{uPA}_{1-43}$-melittin. (a) SDS-PAGE analysis of rhuPA ${ }_{1-43}$-melittin. Lane M, protein molecular weight marker (broad). Lane 1, the supernatant of rhuPA $\mathrm{P}_{1-43}$-melittin. Lane 2, purified huPA $\mathrm{A}_{1-43}$-melittin. (b) Western blot analysis. Lane 1, supernatant of rhuPA $_{1-43}$-melittin before adding methanol as a negative control. Lane 2, purified rhuPA ${ }_{1-43}$-melittin.

$\mathrm{N}$-terminal sequencing of rhuPA $\mathrm{H}_{1-43}$-melittin offered the first 14 amino acids as S N E L H Q V P S N C D C L. The $\mathrm{N}$-terminal sequence of $\mathrm{rhuPA}_{1-43}$-melittin was identical to that of human uPA, confirming the successful expression and purification of rhuPA $1-43$-melittin.

Anticancer effects of rhuPA $A_{1-43}$-melittin. After being treated with rhuPA ${ }_{1-43}$-melittin at different doses, some SKOV3 cells showed membrane blebbing, ballooning and chromatin condensation. However, the cells grew well with adherence and the cells were fusiform or diamond shaped in the control group. MTT assay was used to detect the quantity of cells. As a result, rhuPA $1-43$-melittin treatment brought about a dose-dependent inhibition of growth on SKOV3 at $24 \mathrm{~h}$. The inhibition rate is $\sim 84 \%$ at the dose of $80 \mu \mathrm{g} / \mathrm{ml}$ (Fig. 5). However, the result (Fig. 5) showed that rhuPA ${ }_{1-43}$-melittin did not have much influence on the proliferation of normal cells (HBL100). The reason is that uPAR is highly expressed in ovarian cancer SKOV3 cells, but it is undetectable in normal cells such as HBL100. In other words, the anticancer effect of rhuPA ${ }_{1-43}$-melittin can be exerted when $\mathrm{uPA}_{1-43}$ combines with its receptor-uPAR followed by the release of melittin. So the fusion protein we expressed has no obvious toxicity on normal tissues and it can be applied to ovarian cancer targeted therapy.

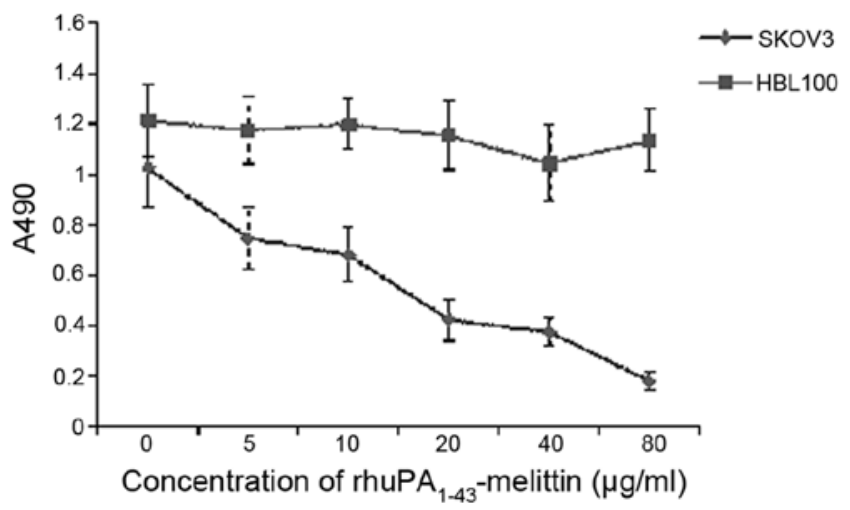

Figure 5. Effects of rhuPA ${ }_{1-43}$-melittin on cell proliferation. Dose-effect curve of inhibition effects of rhuPA $1-43$-melittin on growth of ovarian cancer SKOV3 cells (diamonds). Dose-effect curve of inhibition effects of rhuPA r-43 $_{\text {-melittin }}$ on growth of human breast epithelial HBL100 cells (squares).

To examine whether rhuPA $1-43$-melittin that induced growth inhibition was associated with cell cycle regulation, the cell cycle distribution was analyzed by flow cytometry. After SKOV3 cells were incubated with rhuPA ${ }_{1-43}$-melittin for $24 \mathrm{~h}$, cells were harvested and further prepared for cell cycle 

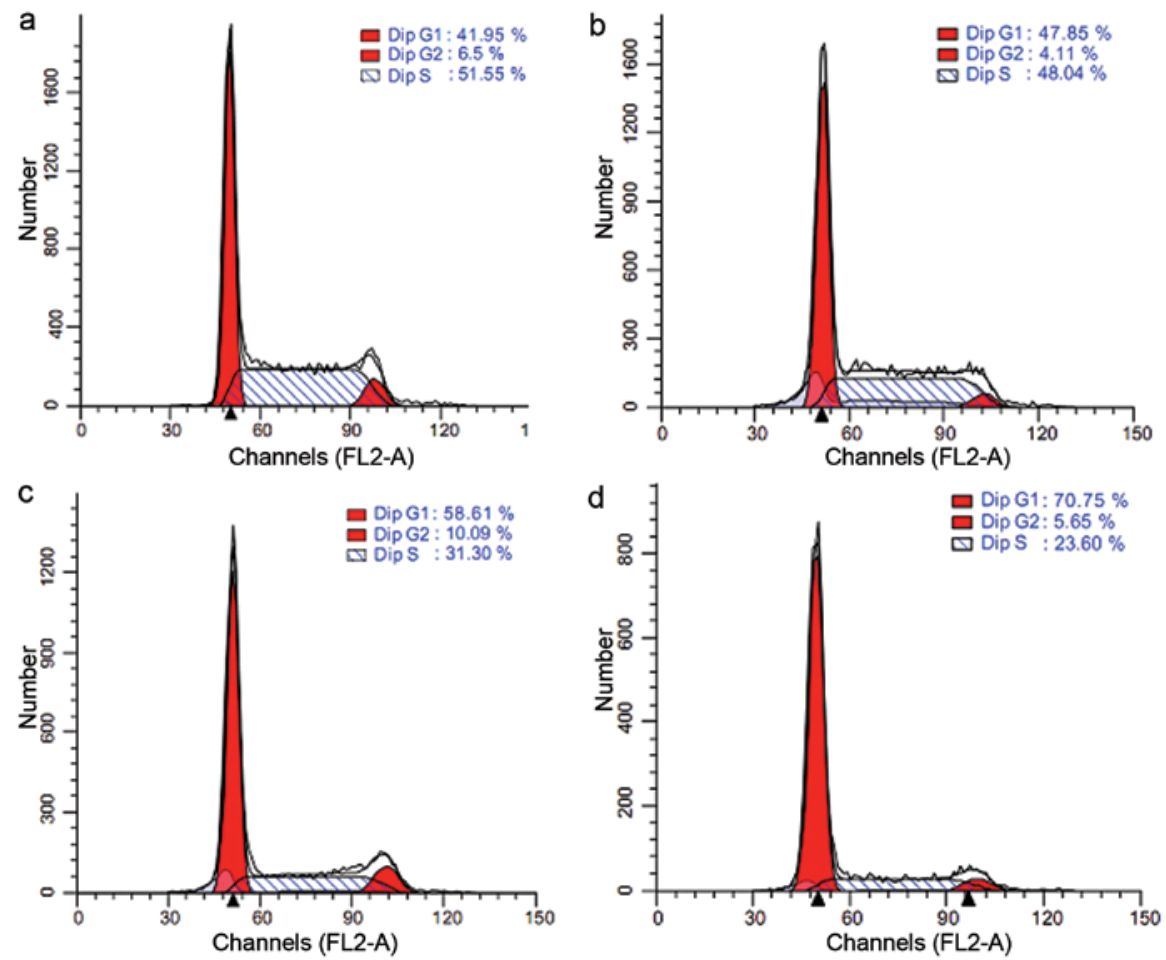

Figure 6. Effects of rhuPA $1-43$-melittin on cell cycle regulation. Cell cycle was detected after SKOV3 cells being treated with different concentration of rhuPA $_{1-43}$-melittin for $24 \mathrm{~h}$. (a) SKOV3 was treated with H-DMEM (as control). (b) SKOV3 was treated with $20 \mu \mathrm{g} / \mathrm{ml} \mathrm{rhuPA}_{1-43}$-melittin. (c) SKOV3 was treated with $40 \mu \mathrm{g} / \mathrm{ml} \mathrm{rhuPA}_{1-43}$-melittin. (d) SKOV3 was treated with $80 \mu \mathrm{g} / \mathrm{ml} \mathrm{rhuPA}_{1-43}$-melittin.
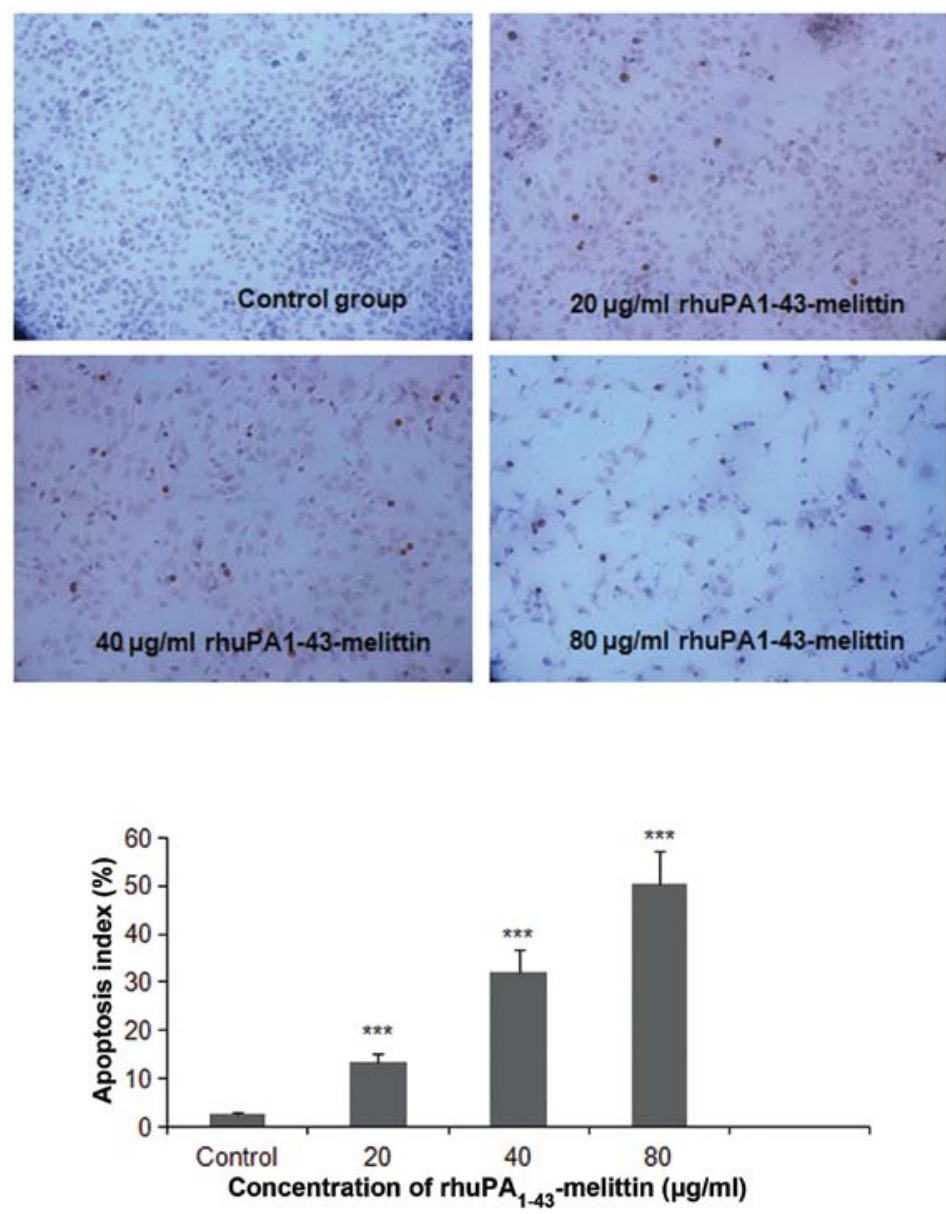

Figure 7. TUNEL assay for apoptosis. TUNEL assay was detected after SKOV3 cells being treated with different concentration of rhuPA $\mathrm{A}_{1-43}$-melittin for $24 \mathrm{~h}$. (a) Morphology of TUNEL assay. SKOVS cells were treated with H-DMEM (as control), 20, 40 and $80 \mu \mathrm{g} / \mathrm{ml} \mathrm{rhuPA}_{1-43}$-melittin, respectively. (b) Apoptosis index of SKOV3 cells after being treated with different concentration of rhuPA ${ }_{1-43}-$ melittin; $^{* * * *} \mathrm{P}<0.001$ vs control group. 
analysis. Of the SKOV3 cells $41.95 \%$ was in the G1 phase under normal growth conditions, while treatment of SKOV3 cells with 20,40 and $80 \mu \mathrm{g} / \mathrm{ml} \mathrm{rhuPA}_{1-43}$-melittin resulted in $47.85,58.61$ and $70.75 \%$ of cells in the G1 phase of the cell cycle, respectively (Fig. 6). These results indicate that rhuPA $_{1-43}$-melittin may induce G1 phase cell cycle arrest of SKOV3 cells.

The TUNEL assay demonstrated that ovarian cancer cells underwent apoptosis after treatment with rhuPA ${ }_{1-43}$-melittin. Data from all designated fields were pooled to obtain the apoptotic index, which is the percentage of TUNEL positive cells in total cells manually counted in 6 random fields. The apoptosis index of rhuPA $\mathrm{PA}_{1-43}$-melittin treatment groups were remarkably increased compared with the normal control group $(\mathrm{P}<0.001)$. As a result, rhuPA $_{1-43}$-melittin treatment caused a dose-dependent increase of apoptosis in SKOV3 within $24 \mathrm{~h}$ (Fig. 7).

\section{Discussion}

The difficulty of complete resection caused by intra-abdominal dissemination and acquired resistance to platinum-based drugs during cyclic chemotherapy has been reported as the main reason for high mortality rate of advanced ovarian cancer (19). Therefore, it has become essential to introduce new therapeutic modalities that may benefit the patients.

Melittin is an attractive anticancer candidate because of its wide-spectrum lytic properties. Although cytotoxic to broad spectrum of tumor cells, the peptide is also toxic to normal cells and its therapeutic potential cannot be achieved without a proper delivery vehicle (20).

The present study focused on expression of a target fusion protein- rhuPA $_{1-43}$-melittin which can be used in ovarian cancer targeted therapy. Taking $\mathrm{uPA}_{1-43}$ amino acids specifically binding to uPAR as targeted part of fusion protein and making use of antitumor activity of melittin, the recombinant fusion protein was able to inhibit invasion and metastasis of ovarian tumor and to be applied for effective targeted treatment.

In this study, $\mathrm{uPA}_{1-43}$-melittin-pPICZ $\alpha \mathrm{C}$ eukaryotic expression vector was constructed. After being transformed into $P$. pastoris and induced by methanol, rhuPA $1-43-$ melittin was detected on the basis of SDS-PAGE and western blot analysis. We established a stable and effective rhuPA ${ }_{1-43}-$ melittin $P$. pastoris expression system. The proteins of $P$. pastoris itself are seldom secreted into the culture medium, and the target protein is easy to be purified and free of problems such as endotoxin pollution (21). Thus, it is possible to establish a solid foundation for large-scale fermentation in the future.

Cell proliferation assay showed that rhuPA $_{1-43}$-melittin could inhibit growth of SKOV3 and had no cytotoxicity on normal cells. Cell cycle arrest and apoptosis are two important mechanisms involved in anticancer drug treatment. The cell cycle plays an important role in cell fate, including cell replication, cell death, and cell function. To explore the underlying mechanism by which rhuPA $1-43$-melittin inhibits SKOV3 cells growth, we determined the cell cycle progression of SKOV3 cells after the treatment with rhuPA ${ }_{1-43}$-melittin for $24 \mathrm{~h}$. Our results demonstrated that treatment of SKOV3 cells with rhuPA $A_{1-43}$-melittin induced cell cycle arrest in the G1 phase, indicating that one of the mechanisms by which rhuPA ${ }_{1-43^{-}}$ melittin inhibits the proliferation of SKOV3 cells is through inhibition of cell cycle progression. TUNEL assay revealed that rhuPA $\mathrm{P}_{1-43}$-melittin induced apoptosis of SKOV3 cells. In conclusion, with rhuPA ${ }_{1-43}$-melittin, it is possible to induce cell cycle arrest, growth inhibition and apoptosis in SKOV3 cells and this study offers the early-stage experimental basis for further study on treatment of ovarian cancer with rhuPA ${ }_{1-43^{-}}$ melittin.

\section{Acknowledgements}

This study was supported by grants from the National Natural Science Foundation of China (81272875, 30973187 and 81302242), the Foundation of Ministry of Education of China for Young Scholars (20110061120084), Jilin Science and Technology Funds (20110755, 20120957 and 20130102094JC, 20140204022YY), basic scientific research of Jilin University Funds and Young Scholars Program of Norman Bethune Health Science Center of Jilin University (20142116).

\section{References}

1. Thummarati P, Wijitburaphat S, Prasopthum A, Menakongka A, Sripa B, Tohtong R and Suthiphongchai T: High level of urokinase plasminogen activator contributes to cholangiocarcinoma invasion and metastasis. World J Gastroenterol 18: 244-250, 2012.

2. Lee DH, Yang Y, Lee SJ, Kim KY, Koo TH, Shin SM, Song KS, Lee YH, Kim YJ, Lee JJ, Choi I and Lee JH: Macrophage inhibitory cytokine-1 induces the invasiveness of gastric cancer cells by up-regulating the urokinase-type plasminogen activator system. Cancer Res 63: 4648-4655, 2003.

3. Blasi F and Carmeliet P: uPAR: a versatile signalling orchestrator. Nat Rev Mol Cell Biol 3: 932-943, 2002.

4. de Bock CE and Wang Y: Clinical significance of urokinase-type plasminogen activator receptor (uPAR) expression in cancer. Med Res Rev 24: 13-39, 2004.

5. Andreasen PA, Egelund R and Petersen HH: The plasminogen activation system in tumor growth, invasion, and metastasis. Cell Mol Life Sci 57: 25-40, 2000.

6. Stepanova VV and Tkachuk VA: Urokinase as a multidomain protein and polyfunctional cell regulator. Biochemistry (Mosc) 67: 109-118, 2002.

7. Botkjaer KA, Deryugina EI, Dupont DM, Gårdsvoll H, Bekes EM, Thuesen CK, Chen Z, Ploug M, Quigley JP and Andreasen PA: Targeting tumor cell invasion and dissemination in vivo by an aptamer that inhibits urokinase-type plasminogen activator through a novel multifunctional mechanism. Mol Cancer Res 10: 1532-1543, 2012

8. Ballance DJ, Marshall JM, Cottingham IR, Steven J, Berry SJ, Cederholm-Williams SA, Goodey AR and Courtney M: A hybrid protein of urokinase growth-factor domain and plasminogenactivator inhibitor type 2 inhibits urokinase activity and binds to the urokinase receptor. Eur J Biochem 207: 177-183, 1992.

9. Rabbani SA, Mazar AP, Bernier SM, Haq M, Bolivar I, Henkin J and Goltzman D: Structural requirements for the growth factor activity of the amino-terminal domain of urokinase. J Biol Chem 267: 14151-14156, 1992.

10. Solberg H, Ploug M, Høyer-Hansen G, Nielsen BS and Lund LR: The murine receptor for urokinase-type plasminogen activator is primarily expressed in tissues actively undergoing remodeling. J Histochem Cytochem 49: 237-246, 2001.

11. Li H, Ye X, Mahanivong C, Bian D, Chun J and Huang S: Signaling mechanisms responsible for lysophosphatidic acidinduced urokinase plasminogen activator expression in ovarian cancer cells. J Biol Chem 280: 10564-10571, 2005.

12. Ljuca D, Fatusić Z, Iljazović E and Ahmetović B: Monitoring of chemotherapy successfulness of platina/taxol chemotherapy protocol by using determination of serum urokinase plasminogen activator (uPA) and soluble urokinase plasminogen activator receptor (suPAR) in patients with ovarian carcinoma FIGO II and III stage. Bosn J Basic Med Sci 7: 111-116, 2007. 
13. Kotzsch M, Bernt K, Friedrich K, Luther E, Albrecht S, Gatzweiler A, Magdolen V, Baretton G, Zietz C and Luther T: Prognostic relevance of tumour cell-associated uPAR expression in invasive ductal breast carcinoma. Histopathology 57: 461-471, 2010.

14. Ulisse S, Baldini E, Sorrenti S and D'Armiento M: The urokinase plasminogen activator system: a target for anticancer therapy. Curr Cancer Drug Targets 9: 32-71, 2009.

15. Shin JM, Jeong YJ, Cho HJ, Park KK, Chung IK, Lee IK, Kwak JY, Chang HW, Kim CH, Moon SK, Kim WJ, Choi YH and Chang YC: Melittin suppresses HIF-1 $\alpha /$ VEGF expression through inhibition of ERK and mTOR/p70S6K pathway in human cervical carcinoma cells. PLoS One 8: e69380, 2013.

16. Li B, Gu W, Zhang C, Huang XQ, Han KQ and Ling CQ Growth arrest and apoptosis of the human hepatocellular carcinoma cell line BEL-7402 induced by melittin. Onkologie 29: 367-371, 2006.
17. Orsolić N, Sver L, Verstovsek S, Terzić S and Basić I: Inhibition of mammary carcinoma cell proliferation in vitro and tumor growth in vivo by bee venom. Toxicon 41: 861-870, 2003.

18. Raghuraman $\mathrm{H}$ and Chattopadhyay A: Melittin: a membraneactive peptide with diverse functions. Biosci Rep 27: 189-223, 2007.

19. Tang J, Li J, Zeng G, Tang Y, Tian W, He J, York JP and Xia X: Antisense oligonucleotide suppression of human IGF-1R inhibits the growth and survival of in vitro cultured epithelial ovarian cancer cells. J Ovarian Res 6: 71, 2013.

20. Gajski G and Garaj-Vrhovac V: Melittin: a lytic peptide with anticancer properties. Environ Toxicol Pharmacol 36: 697-705, 2013.

21. Gurkan C and Ellar DJ: Recombinant production of bacterial toxins and their derivatives in the methylotrophic yeast Pichia pastoris. Microb Cell Fact 4: 33, 2005. 